\title{
Effect of supplementation on reproduction of wet season kidding Tswana goats
}

\author{
O. R. Madibela ${ }^{1 \#}$, B. M. Mosimanyana, W. S. Boitumelo and T. D. Pelaelo \\ Sebele Station, Department of Agricultural Research, P/Bag 0033, Gaborone, Botswana.
}

\begin{abstract}
Seventy-seven mature Tswana goats were used to investigate the effect of supplementation on reproduction of wet season kidding animals. Treatments groups with similar weights were: Unsupplemented Control (UC), Continuous Supplementation (CS), Before Rain Supplementation (BRS) and After Rain Supplementation (ARS). Fertility rate, kidding rate, kid survival rate and doe weight at weaning were similar between the three treatments and the control. Kid birth weights did not differ between treatment groups. Doe parturition weight was higher in $\mathrm{CS}$ and lowest in BRS. Kid average daily gain (ADG) and weaning weight were significantly higher for CS and ARS while they ranked low, but similar between BRS and the control groups. Among ARS animals, doe parturition weight and birth weight tended to be correlated. Kid birth weight was positively correlated with growth rate in the ARS treatment. Productivity index (PI) for CS was high but similar to that of ARS. However PI's for BRS, ARS and the control groups were similar. Average daily gain (104.0 $\pm 4.3 v s .69 .8 \pm 2.8 \mathrm{~g} / \mathrm{d})$ differed between singles and multiples. Survival rates were similar (91.9 vs. 93.9\%) between multiples and singles. This study demonstrated that supplementary feeding can offset the detrimental effects of both maternal and offspring undernutrition during the critical stages of the reproductive cycle of goats.
\end{abstract}

Keywords: Supplementation, reproduction, Tswana goats, productivity index.

${ }^{1}$ Present address: Department of Animal Science and Production, Botswana College of Agriculture, P/Bag 0027, Gaborone,

Botswana.

\#Corresponding author. E-mail: omadibel@temo.bca.bw

\section{Introduction}

Botswana farmers with limited resources, goat production offers an opportunity to alleviate hunger and improve living standards. The short gestation period of goats as compared to cattle means that milk and meat production can be realised within a short period of time. Unlike cattle whose ownership is limited to a small proportion of the population, small ruminants are widely distributed among the population (Panin \& Mahabile, 1997). In 1995, 99\% of the national goat flock of 2.6 million was in the traditional sector (CSO, 1999). The traditional farming system is practiced on communal, unfenced land and breeding is uncontrolled (Nsoso \& Madimabe, 1999), with the males running with the females throughout the year. Animals depend on the veld for almost all of their nutrient supplies. They rarely receive any supplements except for small quantities mineral-salt licks. The supply of nutrients from the veld fluctuates between years and seasons. Goats require a relatively small investment and the simple management required, make them an attractive resource for poor farmers especially female-headed households.

The Tswana goat is an indigenous unselected meat-type goat. According to Senyatso \& Masilo (1996) they constitute about $80 \%$ of the national goat population in Botswana. Due to the high frequency of twinning in the Tswana goat (APRU, 1987; Gray, 1987a; APRU, 1989), their numbers can increase rapidly. Gray (1987a) recorded under communal conditions an annual kidding rate of $137 \%$, ranging from 100 to $217 \%$. Another study (APRU, 1987) reported a kidding rate of $152 \%$, with $50.7 \%$ of the kiddings producing twins. Gray (1987b) also found that in some flocks, does kid every eight months. However, the CSO (1999) reported in both the traditional and commercial sectors a kidding percentage of 43 in flocks of $\leq 20$ animals. Therefore, despite its high prolificacy, low fertility of Tswana goat at farm level is a limitation to increased productivity. Low birth rates may be caused by acyclicity, early embryonic mortality or abortions not noted by the farmer. The effect of photoperiod has not been studied on indigenous goats in Botswana, but according to Silva et al., (1998) photoperiod does not change significantly in the tropics. Therefore, a major factor contributing to the low birth rates in traditionally reared flocks is likely to be nutrition, since goats are kept almost exclusively on the natural veld. According to Ndlovu (1992) nutritional stress appears to be a prime cause of acyclicity in goats. It is, therefore, important for smallholder farmers in Botswana to know when these critical periods of nutritional stress occur which could have an impact on the reproductive activities of their goats. In this study we evaluated the effects of supplementing sorghum stover based diets on the reproduction and productivity of Tswana goats kidding in the wet season. 


\section{Materials and Method}

Seventy-seven indigenous Tswana does ( 2 to 4 years old) were obtained for the study, which lasted for nine months. The does were randomly allocated to the follow treatments: Unsupplemented Control $(\mathrm{UC}, \mathrm{n}=20)$, Continuous Supplementation (CS, $\mathrm{n}=19$ ), Before Rain Supplementation (BRS, $\mathrm{n}=20$ ) and After Rain Supplementation (ARS, $\mathrm{n}=18$ ). During the daytime all the groups had access to the natural grazing at a stocking rate of $2.3 / \mathrm{SSU}$ and they were penned at night. The supplementary diet consisted of $40 \%$ sorghum stover, $14 \%$ wheat bran, $42 \%$ ground maize grain, $2 \%$ molasses, $1.4 \%$ urea, $0.3 \%$ dicalcium phosphate and $0.3 \%$ salt, with an approximate nutrient composition (per $\mathrm{kg} \mathrm{DM}$ of feed) of; $106 \mathrm{~g}$ protein, $4 \mathrm{~g}$ calcium, $3 \mathrm{~g}$ phosphorus and $244 \mathrm{~g}$ acid detergent fibre as well as $10.2 \mathrm{MJ} \mathrm{ME} / \mathrm{kg}$. Supplementation for the treatment, BRS, started on the first day of the trial and continued until a week after the first rains that fell on 18 October. At this stage the ARS treatment started and continued till the end of the trial in April (Figure 1). The supplement was fed on a group basis at an average daily rate of $250 \mathrm{~g} / \mathrm{doe}$, but varied from 200 to $400 \mathrm{~g} / \mathrm{doe} / \mathrm{d}$, depending on the condition of the veld. The bucks received the same supplement at a rate of $500 \mathrm{~g} / \mathrm{animal} / \mathrm{d}$. The study was conducted at the Sebele Research Station, situated in south east of Botswana $\left(24^{\circ} 33^{\prime} \mathrm{S}\right.$ and $\left.25^{\circ} 57^{\prime} \mathrm{E}\right)$, at an altitude of $994 \mathrm{~m}$ above sea level. The vegetation consists of Acacia savanna and broad-leaved middle layer trees. Grass quality and quantity fluctuate with season, being adequate in October to March and in short supply or low in quality between April and September. During the dry season browse supplies most of the nutrients to the goats. The soil is classified as: moderately deep to very deep; imperfectly to moderately well drained; dark brown to red; sandy clay loams to clays (De Wit \& Nachtergaele, 1990). Rainfall and temperature data were collected from the Botswana Meteorology Services weather station located approximately $0.5 \mathrm{~km}$ from Sebele. The mean rainfall for the area is $500 \mathrm{~mm}$. The monthly average minimum and maximum temperatures were 12.8 and $28.6{ }^{\circ} \mathrm{C}$, respectively.

The does had not been bred for at least a year prior to the trial. The bucks joined the does at the start of the trial on the 18th of August and ran with them for the duration of the study. During daytime the four treatment groups grazed together, but were separated at night into their respective groups and received their supplements in these night pens. The bucks were separated from the does at night. By the 18th of October the does were $c$. $60 \mathrm{~d}$ pregnant. Kidding started in January and continued for $c$. two months. Water was available at all times in the grazing paddocks and in the pens. The kids remained in the pens until weaning and had access to their dams' feed in the troughs.

Does were weighed at the start of the trial and at monthly intervals. Within $24 \mathrm{~h}$ of parturition a does and her kids were weighed. The kids were then weighed bi-weekly until weaning. Additional data recorded, included the number of does that kidded, kid mortality and the quantity of supplementary feed offered. A plunge dip $(9 \% \mathrm{v} / \mathrm{v}$ chlorfenvinphos concentrate, Agricura, South Africa) was used for tick control when infestation was observed. The goats were treated for internal parasites using an anthelmitic (Ivomec, Logos Agvet, South Africa) once at the start of the trail.

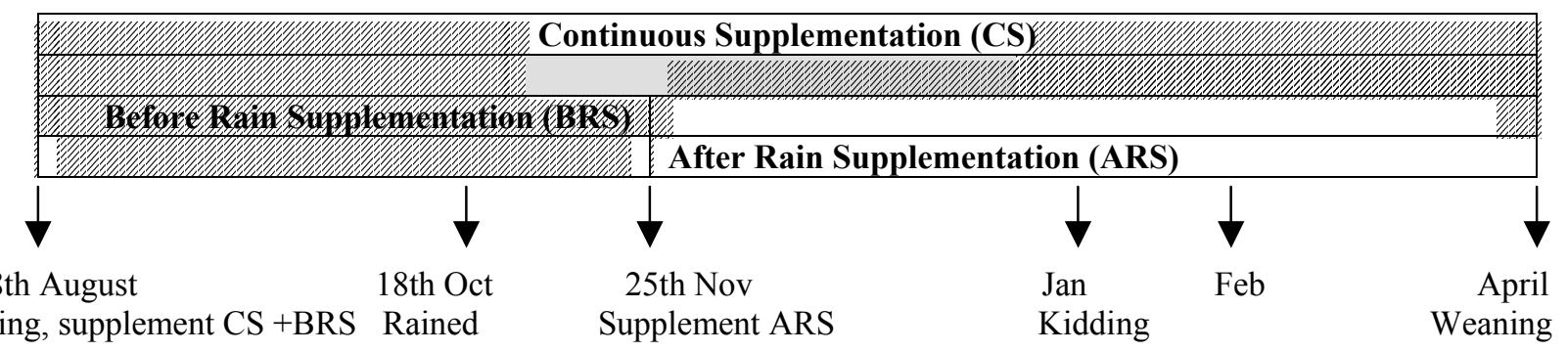

Mating, supplement CS +BRS Rained Supplement ARS Kidding Weaning

Figure 1 Schematic representation of time schedule of reproductive cycle and of supplementation of the does

The experimental design was a complete randomised block and a General Linear Models (GLM) procedure (SAS, 1990) was used. Animals were divided into four equal groups, balanced for body weight and age. In general the model used, was as follows:

Variable $=$ fixed + treatment + co-variate + interaction + error

Variables investigated, were kidding rate, kid birth weight, dam parturition weight, kid daily gain, doe weight at weaning, weaning weight and productivity index. Birth-type, rear-type and sex were fixed effects, while 
doe weight at kidding and kid birth weight were used as co-variates. For kid daily gain and weaning weight, data of a set of multiple births for which one of the siblings died, were discarded. Data for twins or triplets offspring were combined to form data set 'multiples' since only two sets of triplets were involved. Differences between specific treatments were tested for significance by least significant difference (LSD). Productivity index was calculated as fertility rate $\mathrm{x}$ kidding rate $\mathrm{x}$ survival rate $\mathrm{x}$ weaning weight. It estimated the total amount of live weight from live kids at weaning per doe mated. Correlations between kid birth weight and doe parturition weight, birth weight and weaning weight, birth weight and average daily gain (ADG) as well as weaning weight and doe weight at weaning were also calculated. The Chi-square test (SAS, 1990) was used to test effects of treatments on fertility rate and survival rate. The Fisher Exact Test was used when the number of animals in a treatment or fixed effects (i.e. sex and birth type) category was less than five (Steel \& Torrie, 1980). Rear type means the status of how the kids were reared (i.e. as singles or multiples).

\section{Results}

All the treatments had similar effects on fertility rate, kidding rate of does and the birth weight of kids (Table 1). No significant $(\mathrm{P}<0.05)$ difference was found in survival rate between males and females kids $(94.0 v s .91 .2 \%$ respectively). Male kids were born heavier $(\mathrm{P}<0.001)$ than females $(3.2 \pm 0.08$ vs. $2.6 \pm 0.08 \mathrm{~kg})$ and tended $(\mathrm{P}=$ $0.06)$ to have a higher ADG $(92.0 \pm 4.2 v s .88 .0 \pm 4.1 \mathrm{~g} / \mathrm{d})$ and weaning weights $(12.8 \pm 0.6 v s .11 .6 \pm 0.5 \mathrm{~kg})$. There was significant $(\mathrm{P}<0.001)$ treatment effect on doe weight at parturition $(\mathrm{DPW})$, weaning weight of kids and their pre-weaning ADG. Does in CS group had the highest DPW followed by those in ARS, and BRS had the least value. Kids from the CS and ARS groups had similar daily gains but higher than those of BRS and UC. The same trend was observed for weaning weight (Table 1). Biweekly least square weights of kids from birth to 102 days are presented in Figure 2. There were no significant correlations between doe parturition weight and kid birth weight among UC $(\mathrm{r}=-0.19)$, BRS $(\mathrm{r}=-0.26)$ and CS $(\mathrm{r}=0.07)$ animals. Among ARS animals, the weight of the does at parturition was correlated $(\mathrm{r}=0.381, \mathrm{P}=0.073)$ with birth weight of their kids. No significant correlation was observed between doe weight at parturition and kids' growth rate, except in the ARS treatment $(\mathrm{r}=0.44, \mathrm{P}<0.05)$. These values are similar to those between doe parturition weight and kid weaning weight (Table 2). Correlations between kid birth weight and weaning weight varied between treatment groups, but were high and significant $(\mathrm{r}=$ $0.71, \mathrm{P}<0.001)$ among ARS, and tended to be weak $(\mathrm{r}=0.35, \mathrm{P}=0.08)$ among $\mathrm{CS}$ animals. There was, however, no significant correlation among UC $(\mathrm{r}=0.17)$ and BRS $(\mathrm{r}=0.32)$ animals (Table 2). Doe live weights are presented in Figure 3. At weaning there were no significant differences in the live weights of the does. It was found that the correlation between doe weight at weaning and kid weaning weight was positive only in ARS group $(\mathrm{r}=$ $0.48, \mathrm{P}<0.05)$. Although the preweaning survival rate of the kids did not differ statistically among treatments, none of the kids from the ARS group died compared to $13.8 \%$ in the UC group (Table 1).

The productivity indices of the CS and ARS treatments were better $(\mathrm{P}<0.05)$ than those of the group not receiving a supplement or receiving a supplement before the rains. At birth, singles were significantly $(\mathrm{P}<0.001)$ heavier $(3.3 \pm 0.08$ vs. $2.7 \pm 0.05 \mathrm{~kg})$ than multiples. No interaction was found between treatment and birth-type on birth weight. Those kids that were reared as singles grew faster $(\mathrm{P}<0.001 ; 104 \pm 4.3 v s .69 .8 \pm 2.8 \mathrm{~g} / \mathrm{d})$ and were heavier $(\mathrm{P}<0.001 ; 15.8 \pm 0.6$ vs. $10.5 \pm 0.4 \mathrm{~kg})$ at weaning than those reared as multiples. Kids reared as singles in the CS and ARS groups had similar daily gains $(116 \pm 8.2$ vs. $122 \pm 6.9 \mathrm{~g} / \mathrm{d})$ and weaning weights $(17.4 \pm 1.2 v s$. $18.4 \pm 1.0 \mathrm{~kg})$ respectively. These were higher $(\mathrm{P}<0.01)$ than those of the kids in treatments BRS and UC $(87.4 \pm 6.5$ and $92.9 \pm 9.4 \mathrm{~g} / \mathrm{d} ; 13.2 \pm 1.0$ and $14.0 \pm 1.4 \mathrm{~kg})$ respectively. There was no interaction between treatment and rear-type for daily gain and weaning weight, thus multiples from CS and ARS grew at similar rates as singles in the BRS and UC treatments (Table 3).

Rainfall during the experimental period was $278 \mathrm{~mm}$ per year, which was below the long-term mean of 500 $\mathrm{mm}$.

Table 1 The effect of supplementation on reproduction, weights, survival rates and productivity index of Tswana goats (lsmean \pm s.e.) 


\begin{tabular}{lccccc}
\hline \multicolumn{5}{c}{ Supplementation treatments } \\
\hline Variable & CS & BRS & ARS & UC & P level \\
\hline Initial weight $(\mathrm{kg})$ & $36.4 \pm 1.4$ & $36.2 \pm 1.4$ & $35.9 \pm 1.5$ & $35.0 \pm 1.4$ & 0.89 \\
Fertility rate $^{2}(\%)$ & 89.5 & 90.0 & 94.4 & 90.0 & 0.95 \\
Kidding rate $^{3}(\mathrm{kid} / \mathrm{doe})$ & $1.69 \pm 0.14$ & $1.56 \pm 0.13$ & $1.35 \pm 0.13$ & $1.65 \pm 0.13$ & 0.31 \\
Kid birth weight $(\mathrm{kg})$ & $3.0 \pm 0.1$ & $2.8 \pm 0.1$ & $3.1 \pm 0.1$ & $3.0 \pm 0.1$ & 0.16 \\
Dam parturition weight $(\mathrm{kg})$ & $44.7 \pm 0.9^{\mathrm{a}}$ & $38.4 \pm 0.9^{\mathrm{c}}$ & $41.4 \pm 1.0^{\mathrm{b}}$ & $39.9 \pm 0.9^{\mathrm{bc}}$ & 0.0001 \\
Kid ADG $^{4}(\mathrm{~g} / \mathrm{day})$ & $94.2 \pm 4.8^{\mathrm{a}}$ & $75.1 \pm 4.4^{\mathrm{b}}$ & $100.9 \pm 4.3^{\mathrm{a}}$ & $79.0 \pm 5.0^{\mathrm{b}}$ & 0.0003 \\
Weaning weight $^{5}(\mathrm{~kg})$ & $14.2 \pm 0.7^{\mathrm{a}}$ & $11.3 \pm 0.7^{\mathrm{b}}$ & $15.2 \pm 0.7^{\mathrm{a}}$ & $11.9 \pm 0.8^{\mathrm{b}}$ & 0.0003 \\
Kid survival rate to weaning $(\%)$ & 93.0 & 89.3 & 100 & 86.2 & 0.21 \\
Dam weight at weaning $(\mathrm{kg})$ & $40.6 \pm 0.8$ & $38.6 \pm 0.8$ & $39.1 \pm 0.8$ & $38.6 \pm 0.8$ & 0.26 \\
Productivity index $^{6}(\mathrm{~kg} / \mathrm{doe})$ & $19.7 \pm 2.0^{\mathrm{a}}$ & $13.4 \pm 2.0^{\mathrm{b}}$ & $18.3 \pm 2.0^{\mathrm{ab}}$ & $14.0 \pm 2.0^{\mathrm{b}}$ & 0.06 \\
Supplement used $^{7}(\mathrm{~g} /$ doe $/ \mathrm{d})$ & 257 & 248 & 258 & 0 & \\
\hline
\end{tabular}

${ }^{1} \mathrm{CS}$ - continuous; BRS - before rain; ARS - after rain; UC - unsupplemented control.

${ }^{2}$ Percentage of does that kid per does exposed to the buck.

${ }^{3}$ Number of kids born alive per doe kidding.

${ }_{5}^{4}$ Average daily gain.

${ }^{5}$ Weaning weights were adjusted for 150 days of age by formula; (ADG x 150) + Birth weight.

${ }^{6}$ Fertility rate $\mathrm{x}$ Kidding rate $\mathrm{x}$ Survival rate $\mathrm{x}$ Weaning weight.

${ }^{7}$ Average amount fed per day from mating to weaning.

${ }^{*}$ Means within rows with different superscript, $\mathrm{a}, \mathrm{b}$ and $\mathrm{c}$ are significantly different at $\mathrm{P}<0.05$.

Table 2 The effect of supplementation on the correlations (r) between the kids' birth weights, weaning weights and the kids' ADG's and dams' weights at parturition and weaning

\begin{tabular}{|c|c|c|c|c|c|c|c|c|}
\hline & \multicolumn{4}{|c|}{ Birth weight } & \multicolumn{4}{|c|}{ Weaning weight } \\
\hline & \multicolumn{4}{|c|}{ Supplementation treatments $^{1}$} & \multicolumn{4}{|c|}{ Supplementation treatments $^{1}$} \\
\hline & $\mathrm{CS}$ & BRS & ARS & $\mathrm{UC}$ & $\mathrm{CS}$ & BRS & ARS & $\mathrm{UC}$ \\
\hline Birth weight & & & & & 0.35 & 0.32 & $0.71 * *$ & 0.17 \\
\hline $\mathrm{DPW}^{2}$ & $0.07^{4}$ & -0.26 & 0.38 & -0.19 & 0.31 & -0.09 & $0.44 *$ & 0.12 \\
\hline $\mathrm{DWW}^{3}$ & & & & & 0.33 & -0.28 & $0.48 *$ & 0.21 \\
\hline $\mathrm{ADG}^{4}$ & 0.35 & 0.32 & $0.71 * *$ & 0.17 & & & & \\
\hline
\end{tabular}

${ }^{1} \mathrm{CS}$ - continuous; BRS - before rain; ARS - after rain; UC - unsupplemented control

${ }^{2}$ Dam parturition weight, ${ }^{3}$ Dam weight at weaning, ${ }^{4}$ Average daily gain

Levels of significance within rows: $*=\mathrm{P}<0.05$, and $* *=\mathrm{P}<0.001$ 


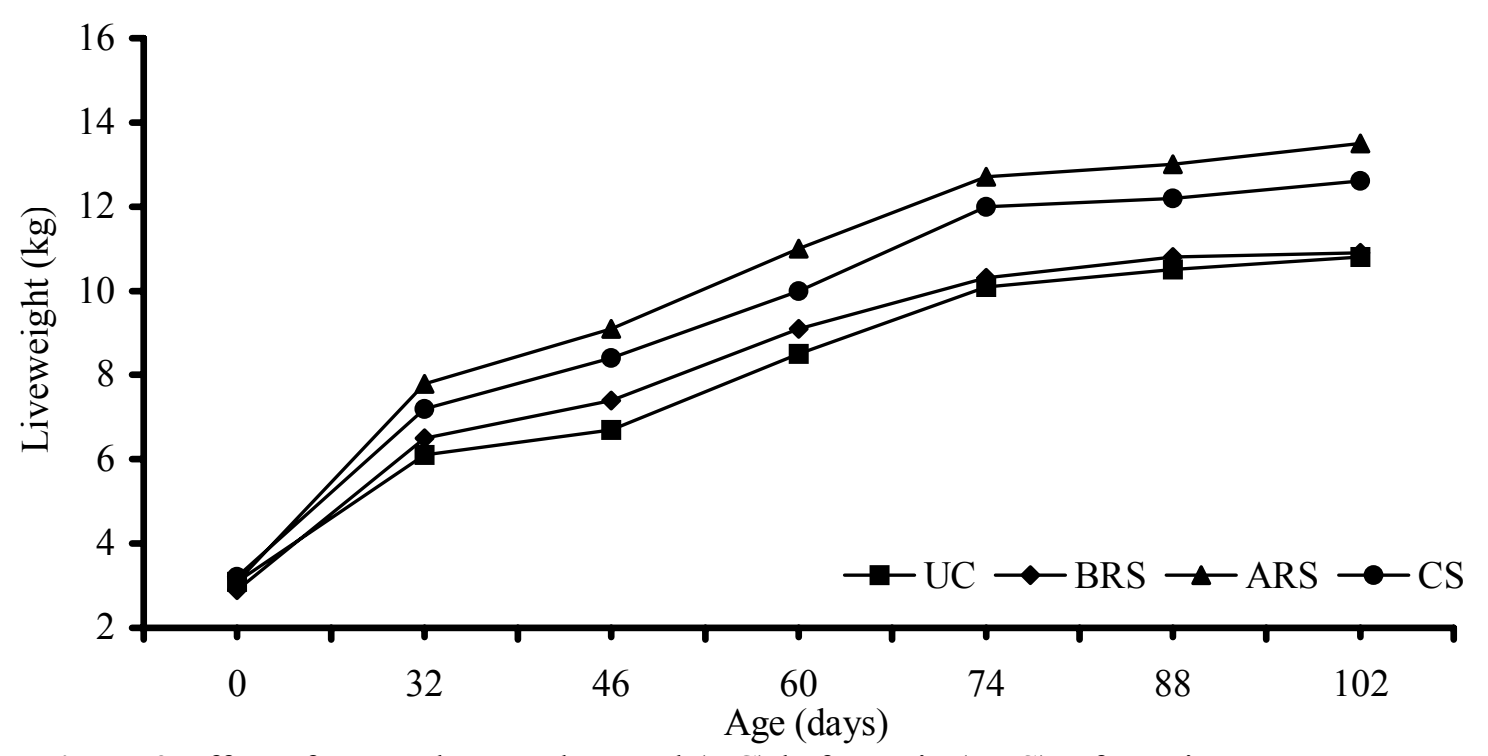

Figure 2 Effect of unsupplemented control (UC), before rain (BRS), after rain

(ARS) and continuous (CS) dam supplementation on kids liveweights

Table 3 The effect of system of supplementation on birth weight, average daily gain (ADG), weaning weight and survival rate of kids (lsmean \pm s.e.)

\begin{tabular}{llcccc}
\hline $\begin{array}{l}\text { Supplementation } \\
\text { treatments }^{1}\end{array}$ & $\begin{array}{l}\text { Birth- or rear- } \\
\text { type }^{2}\end{array}$ & $\begin{array}{c}\text { Birth Weight } \\
\mathrm{Kg}\end{array}$ & $\begin{array}{c}\text { Average Daily Gain } \\
\mathrm{g}\end{array}$ & $\begin{array}{c}\text { Weaning weight } \\
\mathrm{kg}\end{array}$ & $\begin{array}{c}\text { Survival rate } \\
\%\end{array}$ \\
\hline $\mathrm{CS}$ & Multiples & $2.8 \pm 0.1^{\mathrm{cd}}$ & $72.3 \pm 5.0^{\mathrm{cd}}$ & $10.9 \pm 0.7^{\mathrm{bc}}$ & 95.2 \\
& Singles & $3.3 \pm 0.2^{\mathrm{ab}}$ & $116.2 \pm 8.2^{\mathrm{ab}}$ & $17.5 \pm 1.2^{\mathrm{a}}$ & 100.0 \\
$\mathrm{BRS}$ & Multiples & $2.5 \pm 0.1^{\mathrm{d}}$ & $62.8 \pm 6.0^{\mathrm{d}}$ & $9.4 \pm 0.9^{\mathrm{c}}$ & 85.7 \\
& Singles & $3.0 \pm 0.1^{\mathrm{bc}}$ & $87.4 \pm 6.5^{\mathrm{c}}$ & $13.2 \pm 1.0^{\mathrm{b}}$ & 100.0 \\
$\mathrm{ARS}$ & Multiples & $2.6 \pm 0.1^{\mathrm{d}}$ & $79.1 \pm 5.8^{\mathrm{c}}$ & $11.9 \pm 0.9^{\mathrm{bc}}$ & 100.0 \\
& Singles & $3.6 \pm 0.1^{\mathrm{a}}$ & $122.6 \pm 6.9^{\mathrm{a}}$ & $18.4 \pm 1.0^{\mathrm{a}}$ & 100.0 \\
$\mathrm{UC}$ & Multiples & $2.7 \pm 0.1^{\mathrm{cd}}$ & $65.0 \pm 4.9^{\mathrm{d}}$ & $9.8 \pm 0.7^{\mathrm{c}}$ & 90.9 \\
& Singles & $3.5 \pm 0.2^{\mathrm{ab}}$ & $92.9 \pm 9.4^{\mathrm{bc}}$ & $14.0 \pm 1.4^{\mathrm{ab}}$ & 71.4 \\
$\mathrm{P}$ level & & 0.18 & 0.27 & 0.28 & 1.00 \\
\hline
\end{tabular}

${ }^{1}$ CS - continuous; BRS - before rain; ARS - after rain; UC - unsupplemented control.

${ }^{2}$ Birthtype applies to birth weight only, while rear-type applies to ADG, Weaning Weight and Survival Rate.

Means within column with different superscripts $\mathrm{a}, \mathrm{b}, \mathrm{c}$ and $\mathrm{d}$ are significant at $\mathrm{P}<0.05$.

\section{Discussion}

A previous study (APRU 1989) found that fertility rate of wet season kidding in Tswana goats was $81 \%$ which was lower than the value of $91 \%$ for the dry season kidding flock. The difference was attributed to difference in nutrition between the seasons. Results of the present study showed similar fertility rates between treatment groups, suggesting that nutrition did not limit oestrus activity. Treatment diets in a study by MukasaMugerwa et al. (1993) satisfied minimal nutrient requirements for oestrus activity resulting in lack of nutritional effect on oestrus activity of Ethiopian Menz sheep. However, there are other possible explanations for lack of treatment effect on fertility rate in the present study. It is possible that the natural grazing supplied enough nutrients to meet the requirements for ovarian activity and conception, i.e. the energy status of the animals was not limiting. The duration of a year in which the animals were not exposed to pregnancy stress allowed animals to accrue 
enough body reserves to permit instant conception on all treatments. This is consistent with the fact that at mating all animals were in good body condition and had similar live weights. Another plausible explanation may be the attributes of the males in the flock. Having been isolated from the males until mating in August, it is possible that the 'male effect' (Cushwa et al., 1992) may have offset the treatment effect on fertility.

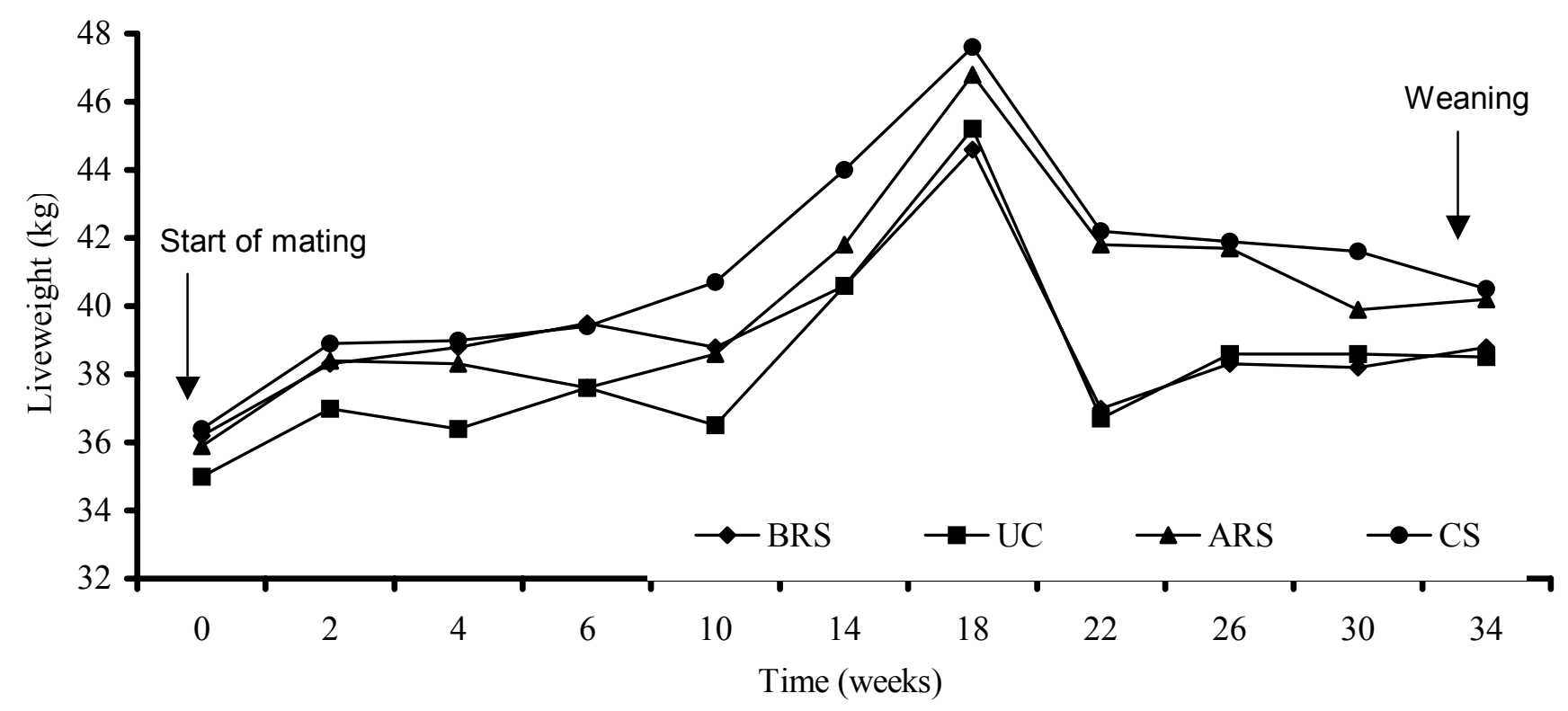

Figure 3 Effect of before rain (BRS), unsupplemented control (UC), after rain (ARS) and continuous (CS) supplementation on weights of breeding Tswana goats

According to McDowell \& Bove (1977), breeds native in lower latitudes usually have above average frequency of multiple births. The kidding rates of the four treatment groups were consistent with past research reports (APRU, 1987) on Tswana goats where 50.7\% of animals kidding in flock in a communal rearing system gave birth to twins. It was, furthermore, found that dry season and wet season kidding resulted in similar kidding rate (1.77 vs. $1.65 \mathrm{kid} /$ doe) under extensive research conditions (APRU, 1989), suggesting that nutrient supply did not influence the number of ova released shed and fertilized. McDowell \& Bove (1977) documented heritability estimates for multiple births to be $8-10 \%$ in goats. Further studies are needed to separate the effect of nutrition from genetic attributes and then to deliberately breed for twinning in order to increase local meat production. An increased number of weaners (due to twinning) can then be subjected to an intensive feeding program to meet the demand for finishing animals, especially during the festive seasons.

Sixty days from post mating to parturition both BRS and UC does were exposed to the same regime, i.e. no feeding. It could, therefore, be expected that their kids' birth weights should be different from those of CS and ARS. The lack of significant difference may be explained by other reports (Robinson, 1990; Wallace et al., 1997; Perry et al., 1999; Robinson et al., 1999; Wallace et al., 1999), that indicated that nutrient restriction at midpregnancy in sheep and cattle may enhance foetal growth by stimulating placental growth and function. Thus, in the present study, BRS and UC may have developed more placental mass in order to increase nutrient supply to the foetus. This possibility is confirmed by the fact that at parturition BRS and UC does had significantly lower weights, while the kid birth weights were similar across treatments. It showed that doe live weight and doe parturition weight did not influence kid birth weight. This is consistent with the insignificant and in some cases (i.e. BRS and UC) negative correlation between dam parturition weights and birth weights. Further studies are needed to quantify placental mass of goats subjected to nutritional regimes similar to those of the present study. 
These results may suggest that it would not be necessary to feed pregnant goats at times which coincide with those of ARS and CS, i.e. late pregnancy, for the purpose of increasing birth weight. This calls for precision feeding strategies throughout the reproductive cycle to save on feeding costs.

The differences in doe weight at parturition were consistent with monthly live weights of the does (Figure 3), which were higher for CS and ARS than the other groups. The lack of a difference in doe weight at weaning shows that, as kids changed from being wholly dependent on milk to using solid feed, lactation stress was reduced, allowing doe weight in the unsupplemented groups to improve. Throughout the trial the live weights of kids (Figure 2) in the ARS and CS treatments were higher than that of BRS and UC. This was consistent with the observed live weight performance of their dams. This suggested that it would be advisable to supplement does during lactation to improve growth and survival rates of the kids. This also indicated the benefits of providing feed to offsprings since these had access to their dams' supplementary feed. Positive and significant correlations between birth weight and weaning weight, and birth weight and daily gain observed only in ARS, probably reflected the nutritional advantages kids in this group had due to low number of multiples. This, in addition to low correlations between birth weight and weaning weight, and birth weight and daily gain in unsupplemented groups indicated additive effects of prenatal and postnatal nutrition on growth of goats. The supplemented nursing does were able to provide enough milk to their kids, who attained $21 \%$ higher daily weight gains compared to those of unsuplemented dams. Body condition of the does during the last trimester and at parturition influences colostrum and milk production (Robinson 1990). In the present study this is confirmed by the correlation of both daily gain and weaning weight, with dam parturition weight which were positive for ARS but low or negative for BRS and UC respectively.

The values of survival rates observed in the present study were similar to those reported by APRU (1989) for wet season but higher than those for dry season kidding in Tswana goats. Low kid survival rates for dry season kidding goats in research ranches (APRU, 1989) that are comparable to those of singles kids from unsupplemented control (UC) group in the present study were attributed to undernutrition. The much lower survival rates of kids born as singles compare to that of multiples in ARS and CS groups, were not expected, since singles were born heavier and should have had a better chance of survival. It shows that the initial low birth weight of multiples was not of the magnitude that would predispose them to higher mortality. However, single kids born from UC group had lower survival rates than single kids born from other treatments.

Kids reared as singles from CS and ARS grew faster and were heavier at weaning than BRS and UC kids, emphasising the added advantages the single-born kids had from these groups (CS and ARS) as a result of the feeding intervention. Lack of interaction between treatment and rear-type for growth rate and weaning weight means that specific treatments difference had the same effect on both singles and multiples for growth rate and weaning weight, a phenomena reported earlier by Nordby et al. (1987). This points to the fact that where nutritional supplementation is practised, multiples will perform similar to singles from unsupplemented flocks. Studies on cellular parameters of prenatal lambs (Rattray et al., 1975) and on birth weights of lambs (Nordby et al., 1987) reported similar performance between the low plane singles, low plane multiples and high plane multiples, a phenomena characteristic of postnatal growth performance of kids in the present study.

The initial birth weights were similar across treatment and variation in birth weight was mostly attributable to multiple births. The temptation to sacrifice one of the siblings of a twinning birth to improve performance of the resultant unsupplemented single kid is not supported by the results of a recent study (Greenwood et al., 2000). The legacy of slow prenatal growth, hence low birth weight due to half the amount of nutrients being supplied during foetal growth in does carrying twins, stays with the offspring during postnatal life even when adequate nutrition is restored. Greenwood et al. (2000) found that low birth weight lambs due to multiple birth continued to have less DNA at any given muscle weight. A recent review by Robinson et al. (1999) pointed out that nutrition during foetal growth and indeed during early- and mid- pregnancy could impact a legacy of developmental changes that affect size, viability and health of neonatal and its postnatal performance. A study by Greenwood et al. (1998) had previously found that lambs born with low birth weight have the capacity to grow at similar rates as their high birth weight counterparts when the low birth weight lambs are adequately fed liquid feed, but apparently that growth was attributed to increase fatness. This increase in fat is not an efficient way of utilising energy for growth and may not necessarily meet market preferences for lean meat. Feeding liquid feed is not feasible for smallholder goat farmers in Botswana due to feed costs, but there is scope to investigate the use of locally available feedstuffs as creep feed.

The results of the present study clearly show the potential of improved feeding management on the productivity index. Supplementation before the rain from mating to Day 60 of pregnancy did not improve productivity. This was due to the fact that reproductive activities coincided with the end of the normal dry season 
and thus the BRS group was not exposed to supplementation for a long time. The ARS group had low kidding rate, i.e. more single kids, but this was compensated by higher weaning weights and survival rates, thereby achieving a higher productivity index. The present findings also dispel the fears that multiples or twinning is not a good trait in Tswana goats.

\section{Conclusions}

Survival rates and growth rates were improved by supplementation, as was the case in ARS, resulting in higher productivity index. Where nutritional supplementation is introduced it is biologically sensible to encourage multiple births since the productivity index from the resultant twinning would double. This study showed that it would not be necessary to feed pregnant grazing goats when the veld condition is good for the purpose of improving kid birth weight. However during lactation it would be advisable to supplement to improve growth and survival rates of kids especially when rain is below the long-term average for the area. Therefore supplementation throughout the reproductive cycle, when the veld condition is good, would not be beneficial. These findings herald a new chapter in the management decisions of small ruminants communal farmers but there should be interpreted in the light that there are feed costs involved. Cost benefit analysis for supplementation is needed even where farmers have crop residues in their farms.

\section{Acknowledgements}

The assistance of B. Sebolai (Botswana College of Agriculture), J. Makore and G. Jeyaruban (DAR) with statistical analyses is appreciated and J.J. Robinson (Scottish Agricultural Colleges, Aberdeen, UK) for his constructive inputs in the preparation of the manuscript. The study was supported financially by Botswana's Ministry of Agriculture.

\section{References}

APRU, 1987. Effect of kidding on goat production. Animal Production Research Unit (APRU), Livestock and Range Research in Botswana, Ministry of Agriculture. Government Printers, Gaborone. pp.73-76.

APRU, 1989. Effect of kidding on goat production. Animal Production Research Unit (APRU), Livestock and Range Research in Botswana, Ministry of Agriculture. Government Printers, Gaborone. pp. 36-41.

Cushwa, W.T., Bradford, G. E., Stabenfeldt, G. H., Berger, Y. M., \& Dally M. R., 1992. Ram influence on ovarian and sexual activity in anestrous ewes; effects of isolation of ewes from rams before joining and date of ram introduction. J. Anim. Sci. 70, 1195-1200

CSO, 1999. Botswana Agricultural Survey Report -1995. Central Statistics Office (CSO), Ministry of Finance and Development Planning. Printing and Publishing Services, Gaborone.

De Wit, P.V. \& Nachtergaele, F.O., 1990. Explanatory note on soil mapping of the Republic of Botswana. FAO/UNDP/Government of Botswana. Soil Mapping and Advisory Services Project (FAO/BOT/85/011), Field Document 30.

Gray, R.C., 1987a. Goat production by Agricultural Technology Improvement Project (ATIP) farmers during 1986 in Tutume District, Botswana. Progress Report. Ministry of Agriculture, Botswana and Mid-America International Agricultural Consortium.

Gray, R.C., 1987b. Livestock Inventory changes on Agricultural Technology Improvement Project (ATIP) farms, Tutume District, Botswana, 1984-1986. Progress Report. Ministry of Agriculture, Botswana and MidAmerica International Agricultural Consortium.

Greenwood, P.L., Hunt, A.S., Hermanson, J.W. \& Bell, A.W., 1998. Effects of birth weight and postnatal nutrition on neonatal sheep: I. Body growth and composition, and some aspects of energetic efficiency. J. Anim. Sci. 76, 2354-2367.

Greenwood, P.L., Hunt, A.S., Hermanson, J.W. \& Bell, A.W., 2000. Effects of birth weight and postnatal nutrition on neonatal sheep: II Skeletal muscle growth and development. J. Anim. Sci. 78, 50-61.

Madibela, O.R., Boitumelo, W.S. \& Letso, M., 2000. Chemical composition and in vitro dry matter digestibility of parasitic plants (Tapinanthus lugardii, Erianthenum ngamicum, Viscum rotundifolium and Viscum verrucosum) in Botswana. Anim. Feed Sci. Technol. 84, 97-106.

McDowell, R.E. \& Bove, L., 1977. The goat as a producer of meat. Cornell Int. Agric. Mimeograph 56, Dept. Anim. Sci., Cornell University. 
Mukasa-Mugerwa, E., Anindo, D., Lahlou-Kassi, A., Mituga, E.R. \& Sovani, S., 1993. Seasonal variation in ovarian and oestrous activity of Tropical Menz sheep as affected by plane of nutrition. Reprod. Nutr. Dev. 33, 585-595.

Ndlovu, L.R., 1992. Reproductive performance of indigenous goats in traditionally managed flocks in North-East of Zimbabwe. In: Small Ruminant Research and Development in Africa. Eds. Lebbie, R.B. \& Reynolds, S.H.B., Proc. First Biennial Conf. Africa Small Ruminant Network. ILRAD, Nairobi, Kenya, Dec. 1990. ILCA, Nairobi, Kenya. pp. 177-184.

Nordby, D.J., Field, R.A., Riley, M.L. \& Kercher, C.J., 1987. Effects of maternal undernutrion during early pregnancy on growth, muscle cellularity, fiber type and carcass composition in lambs. J. Anim. Sci. 64, 1419-1427.

Nsoso, S.J. \& Madimabe, M.J., 1999. The sheep industry in Botswana: promoting the Karakul sheep industry. S. Afr. J. Anim. Sci. 29, 285-262.

Panin, A. \& Mahabile, M., 1997. Profitability and house-hold contribution of small ruminants to small-scale farmers in Botswana. Small Rum. Res. 2, 9-15.

Perry, V.E.A., Norman, S.T., Owen, J.A., Daniel, R.C.W. \& Phillips, N., 1999. Low dietary protein during early pregnancy alters bovine placental development. Anim. Reprod. Sci. 55, 13-21.

Rattray, P.V., Robinson, D.W., Garrett, W.N. \& Ashmore, R.C., 1975. Cellular changes in the tissue of lambs during fetal growth. J. Anim. Sci. 40, 783-788.

Robinson, J.J., 1990. Nutrition in the reproduction of farm animals. Nutr. Res. Rev. 3, 253-276.

Robinson, J.J., Sinclair, K.D. \& McEvoy, T.G., 1999. Nutritional effects on foetal growth. Anim. Sci. 68, 315-331.

SAS., 1990. Statistical Analysis Systems User's Guide. Version 6, SAS Institute INC, Cary, NC. USA.

Senyatso, E.K. \& Masilo, B.S., 1996. Animal genetic resources in Botswana. In: Animal Genetic Resources Information; No 17. Food and Agricultural Organisation and United Nations Environment Programme. Rome. pp. 57-68.

Silva, E., Galina, M.A., Palma, J.M. \& Valencia, J., 1998. Reproductive performance of Alpine dairy goats in semiarid environment of Mexico under a continuous breeding system. Small Rumin. Res. 27: 79-84.

Steel, R.G.D. \& Torrie, J.H., 1980. Principles and Procedures of Statistics, a Biometrical Approach. $2^{\text {nd }}$ ed. McGraw-Hill Book Co. New York. pp. 504-506.

Wallace, J.M., Bourke, D.A., Palmer, R.M. \& Da Silva, P., 1999. Nutrition and the pregnant adolescent. Rowett Res. Inst. Annual Report. pp. 36-39.

Wallace, J.M., Aitken, R.P., Cheyne, M.A. \& Humblot, P., 1997. Pregnancy-specific protein B and progesterone concentrations in relation to nutritional regime, placental mass and pregnancy outcome in growing adolescent ewes carrying singleton fetuses. J. Reprod. Fertil. 109, 53-58. 